\title{
INDIKASI CURRENT RATIO DALAM PENINGKATAN HARGA SAHAM
}

\author{
Sri Dewi Anggadini \\ Universitas Komputer Indonesia \\ dewianggadini8@gmail.com \\ Sari Damayanti \\ Institut Agama Islam Shalahuddin Al-Ayyubi \\ ummijauhar@gmail.com
}

\begin{abstract}
Abstrak. Indikasi Current Ratio Dalam Peningkatan Harga Saham. Tujuan dari penelitian ini adalah untuk mempelajari indikasi dari Current Ratio terhadap Harga Saham. Metode yang digunakan dalam penelitian ini adalah metode deskriptif dan metode verifikatif dengan diskusi kuantitatif. Sumber data yang digunakan adalah data sekunder. Populasi dalam penelitian ini adalah laporan keuangan Perusahaan Sektor Perdagangan Ritel yang terdaftar di Bursa Efek Indonesia sebanyak 25 perusahaan dengan laporan keuangan yang terdiri dari laporan posisi keuangan dan harga saham yang disetujui selama 5 periode (2014-2018). Berdasarkan hasil penelitian dan diskusi, dapat disimpulkan bahwa Current Ratio (CR) memiliki pengaruh yang signifikan terhadap Harga Saham Perusahaan Perdagangan Ritel disamping memiliki hubungan positif antara Current Ratio dan Harga Saham.
\end{abstract}

Kata kunci: Current Ratio (CR); Harga saham

Abstract. Indication of Current Ratio in Increasing Stock Prices. The purpose of this study is to study the indication of Current Ratio to Stock Prices. The method used in this research is descriptive method and verification method with quantitative discussion. The data source used is secondary data. The population in this study is the financial statements of the Retail Trade Sector Companies listed on the Indonesia Stock Exchange as many as 25 companies with financial statements consisting of statements of financial position and share prices approved for 5 periods (2014-2018). Based on the results of research and discussion, it can be concluded that the Current Ratio $(C R)$ has a significant effect on the Stock Price of a Retail Trading Company that has a positive relationship between the Current Ratio and the Stock Prices.

Keywords: Current Ratio (CR); Stock Price

\section{PENDAHULUAN}

Perkembangan pasar modal saat ini menunjukkan perkembangan yang penting sebagai salah satu penggerak utama perekonomian Indonesia. Hal ini terjadi karena semakin meningkatnya minat masyarakat tentang pasar modal, jumlah perusahaan yang terdaftar di pasar modal yang semakin banyak, dan dukungan pemerintah melalui kebijakan berinvestasi. Bursa Efek Indonesia sebagai salah satu pasar modal yang ada di Indonesia.
Bursa Efek Indonesia (BEI) berperan sangat penting diantaranya bagi masyarakat sebagai sarana untuk berinvestasi pada beberapa perusahaan. Selain itu, bagi perusahaan go public sebagai sarana mendapat tambahan modal dengan menerbitkan saham yang ditawarkan ataupun yang diperdagangkan di pasar modal. Daya tarik investor untuk melakukan investasi saham salah satunya terletak pada harga saham. 


\section{Nominal: Barometer Riset Akuntansi dan Manajemen \\ P-ISSN: 2303-2065 E-ISSN: 2502-5430 \\ Volume 10 No 1 (2021)}

Harga saham yang berlaku di bursa efek selalu mengalami perubahan tidak dapat diperkirakan secara pasti. Salah satu indikator yang dipergunakan oleh investor untuk menilai suatu perusahaan dari harga saham dengan melihat kinerja keuangan perusahaan melalui rasio keuangan. Terdapat beberapa rasio keuangan yaitu rasio likuiditas, rasio aktivitas, rasio solvabilitas, rasio profitabilitas, rasio pertumbuhan, dan rasio penilaian (Kasmir, 2017:106).

Harga saham tersebut merupakan harga per saham yang berlaku di pasar modal. Harga saham merupakan kunci yang sangat penting dan harus diperhatikan oleh investor dalam berinvestasi karena harga saham menunjukkan kinerja emiten. Harga saham di 2 pasar modal terdiri dari tiga kategori, yaitu harga tertinggi (high price), harga terendah (harga murah) dan harga penutupan (close price). Harga tertinggi atau terendah adalah harga tertinggi atau terendah yang terjadi pada satu hari perdagangan. Harga penutupan adalah harga terakhir yang terjadi pada akhir jam bursa (Egam, Ilat, dan Pangerapan 2017).

Rasio yang digunakan dalam penelitian ini adalah rasio likuiditas. Rasio likuiditas yang digunakan adalah Current Ratio. Rasio ini mengukur kemampuan perusahaan dalam membayar jangka pendek. Current ratio merupakan salah satu ratio.

CA dikenal sebagai rasio yang sering direkomendasikan dalam perhitungan mengukur kemampuan perusahaan dalam memenuhi kewajiban atau utangnya pada jangka pendek, di mana dapat dilihat seberapa jauh aset perusahaan saat ini dapat menjamin utangnya saat ini (Ismail 2016). Semakin tinggi rasio berarti bahwa utang perusahaan akan dijamin kepada kreditur. Rasio ini digunakan untuk mengukur kemampuan perusahaan untuk membayar kewajiban jangka pendek menggunakan aset lancar yang dimiliki.

Salah satu industri yang mengalami penurunan adalah sektor perdagangan ritel berupa jatuhnya harga saham, sehingga menuntut perusahaan untuk selalu waspada saat pengambilan keputusan karena keputusan yang diambil akan berdampak pada kelangsungan (survive) perusahaan pada masa yang akan datang (Tan, Syarif dan Ariza, 2014). Perusahaan perdagangan ritel sebenarnya adalah industri yang menjanjikan untuk menjadi tempat investasi. Kondisi ini mendorong pemerintah untuk selalu mengajak perusahaan untuk beralih perdagangan ritel massal karena keberlangsungan hidup perusahaan lebih menjanjikan (Tahir Akhtar, 2020). Oleh karena itu, saham di sektor sektor perdagangan ritel dan penyedia perdagangan ritel massal pasti akan menjadi incaran investor karena begitu menjanjikan di masa depan. Perusahaan perlu mengembangkan kegiatan bisnis mereka dalam upaya untuk 


\section{Nominal: Barometer Riset Akuntansi dan Manajemen \\ P-ISSN: 2303-2065 E-ISSN: 2502-5430 \\ Volume 10 No 1 (2021)}

meningkatkan bisnis mereka ke tingkat yang lebih tinggi, yang tentu saja tidak dapat dipisahkan dari persyaratan pendanaan yang relatif besar. Oleh karena itu, perusahaan akan didorong menuju ke pasar modal untuk mendapatkan dana sesuai dengan yang diajukan (Dita dan Saifi 2017).

Salah satu perusahaan sub sektor perdagangan eceran yaitu PT Ace Hardware Indonesia Tbk mengalami penurunan Current Ratio (CR) pada tahun 2017 sebesar 0,24\% dan tahun 2018 sebesar $0,53 \%$, tetapi tidak diikuti dengan kenaikan harga saham yang justru mengalami kenaikan pada tahun 2017 sebesar Rp.320 dan pada tahun 2018 sebesar Rp. 335. Namun keadaan tersebut seharusnya tidak terjadi karena apabila current ratio yang menurun, seharusnya harga saham pun menurun begitupun sebaliknya. Dengan kondisi ini, current rasio memiliki indikasi terhadap harga saham seperti yang diungkapkan oleh Hakkı Öztürk \& Tolun A. Karabulut (2018) yang menyatakan bahwa perubahan baik peningkatan maupun penurunan yang terjadi pada harga saham, tidak terlepas dari current ratio pada saat periode tersebut. Sri Dewi Anggadini \& Eva Tarsiah (2017) dalam penelitiannya menyatakan bahwa current ratio memiliki pengaruh terhadap harga saham dengan korelasi positif, semakin tinggi current ratio maka semakin tinggi pula harga saham, begitu juga sebaliknya. Keberadaan peningkatan harga saham tidak terlepas dari penilaian current ratio (Marie Ligocka \& Daniel Stavarek, 2019).

\section{KAJIAN LITERATUR}

\section{Laporan Keuangan}

Laporan keuangan pada dasarnya merupakan laporan yang berisi informasi keuangan sebuah organisasi. Laporan keuangan yang diterbitkan oleh perusahaan merupakan hasil proses akuntansi yang dimaksudkan sebagai sarana mengkomunikasikan informasi keuangan terutama kepada pihak eksternal. Definisi laporan keuangan menurut Irham Fahmi (2012:2), Laporan keuangan merupakan suatu informasi yang menggambarkan kondisi keuangan suatu perusahaan, dan lebih jauh informasi tersebut dapat dijadikan sebagai gambaran kinerja keuangan perusahaan tersebut.

Menurut Ely Suhayati dan Sri Dewi Anggadini (2009:14) tujuan laporan keuangan adalah menyediakan informasi yang menyangkut posisi keuangan kinerja serta perubahan posisi keuangan suatu perusahaan yang bermanfaat bagi sejumlah besar pemakai dalam pengambilan keputusan ekonomi.

\section{Current Ratio (CR)}

Menurut Bambang Riyanto (2013:28), Current Ratio adalah perbandingan antara 


\section{Nominal: Barometer Riset Akuntansi dan Manajemen \\ P-ISSN: 2303-2065 E-ISSN: 2502-5430 \\ Volume 10 No 1 (2021)}

aktiva lancar dengan utang lancar, maka setiap transaksi yang mengakibatkan perubahan jumlah aktiva lancar atau utang lancar baik masing-masing atau keduaduanya, akan dapat mengakibatkan perubahan current ratio, yang ini berarti akan mengakibatkan perubahan tingkat likuiditas. Adapun menurut penelitian Yemima (2012) menjelaskan, suatu perusahaan yang memiliki current ratio (CR) yang tinggi menunjukkan kondisi yang baik karena apabila nilai CR yang tinggi menunjukkan bahwa suatu perusahaan memiliki kemampuan dalam pembayaran kewajibannya dan mampu memenuhi segala kebutuhan terkait keuangan (Sri Dewi Anggadini, 2018).

\section{Harga Saham}

Harga saham adalah harga yang terjadi di pasar bursa pada saat tertentu yang ditentukan oleh pelaku pasar dan ditentukan oleh permintaan dan penawaran saham yang bersangkutan di pasar modal (Jogiyanto 2016:167). Perubahaan tersebut tergantung pada kekuatan permintaan dan penawaran. Apabila suatu saham mengalami kelebihan permintaan, maka harga saham akan cenderung naik. Sebaliknya, apabila kelebihan penawaran, maka harga saham cenderung turun. Indikator harga saham pada penelitian ini diambil dari nilai harga saham penutup (close price).

\section{Hubungan Current Ratio terhadap Harga}

\section{Saham}

Menurut Birgham (2014:135), Current Ratio merupakan salah satu rasio yang mengukur likuiditas perusahaan. Semakin tinggi kemampuan perusahaan untuk memenuhi utang jangka pendek, hal itu menunjukkan bahwa perusahaan sangat baik atau sehat dan akan menarik investor untuk berinvestasi, sehingga harga saham akan meningkat.

Hal ini sejalan dengan penelitian yang dilakukan Jeany Clarensia et. al.(2011) menemukan Current ratio berpengaruh positif terhadap harga saham pada perusahaan manufaktur.

$\mathrm{H}_{1}$ : Current Ratio berpengaruh signifikan terhadap Harga Saham

\section{METODE PENELITIAN}

Metode yang digunakan dalam penelitian ini adalah metode deskriptif dan metode verifikatif dengan pendekatan kuantitatif, karena adanya variabel-variabel yang diteliti, yaitu harga saham yang dipengaruhi oleh current ratio.

\section{Operasionalisasi Variabel}

Menurut Umi Narimawati (2010:31), Operasionalisasi Variabel merupakan menggunakan unsur-unsur yang lebih kecil dari variable seperti dimensi dan indicator, dimana hal ini menunjukkan ukuran untuk 


\section{Nominal: Barometer Riset Akuntansi dan Manajemen \\ P-ISSN: 2303-2065 E-ISSN: 2502-5430 \\ Volume 10 No 1 (2021)}

menentukan besaran yang dimiliki oleh variable penelitian. Selanjutnya dilakukan analisis factor dalam rangka penjelasan lebih lanjutterkait konseptual penelitian. Dalam penelitian ini menggunakan tiga variabel, yaitu Harga Saham (Y) sebagai varibel terikat, Current Ratio (X) sebagai variabel bebas.

\section{Sumber Data}

Penelitian ini menggunakan sumber data sekunder. Menurut Sugiyono (2017:137), sumber data sekunder merupakan sumber yang tidak langsung memberikan data kepada pengumpul data, misalnya dari orang lain atau lewat dokumen. Data sekunder yang diteliti untuk menghasilkan informasi dari data yang telah diolah yaitu dari laporan keuangan perusahaan perdagangan eceran yang terdaftar di BEI periode 2014-2018.

\section{Teknik Pengumpulan Data}

Teknik pengumpulan data yang digunakan peneliti dalam penelitian dengan data yang diperoleh merupakan data sekunder yang diperoleh dengan cara:

a. Observasi, dengan cara aktivitas mengamati langsung berdasarkan literature yang diperoleh baik dari perpustakaan maupun dari perusahaan, termasuk dalam mengamati data sekunder seperti laporan keuangan.

b. Dokumen-dokumen, dengan cara mencatat data yang berhubungan dengan masalah yang akan diteliti dari dokumen-dokumen yang berhubungan dengan perusahaan.

c. Penelitian Kepustakaan (Library Research), diperoleh dari analisis dan mengkaji seluruh litaeratur, referensi, modul, penelitian sebelumnya, jurnal mengenai konsep variable yang diangkat dalam penelitian termasuk mencari sumber fenomena dari para pakar.

\section{Populasi}

Populasi dalam penelitian ini adalah laporan keuangan Perusahaan Sub Sektor Perdagangan Eceran yang terdaftar di Bursa Efek Indonesia sebanyak 25 perusahaan dengan laporan keuangan yang terdiri dari laporan posisi keuangan dan harga penutupan saham yang dipublikasikan selama 5 periode yaitu dari tahun 2014-2018.

\section{Penarikan Sampel}

Sampel dalam penelitian ini adalah purpossive sampling. Menurut Sugiyono (2017: 84) mendefinisikan purpossive sampling adalah teknik penentuan sampel dengan pertimbangan tertentu. Dengan pertimbangan sebagai berikut:

1. Perusahaan Sub Sektor Perdagangan Eceran yang terdaftar di BEI selama periode 2014-2018.

2. Adanya fenomena yang berhubungan dengan variabel yang diteliti pada laporan keuangan tersebut. 
3. Perusahaan Sub Sektor Perdagangan Eceran laporan keuangan tahunan yang memperoleh laba berturut-turut selama periode 2014-2018.

Berdasarkan kriteria diatas sampel yang diambil adalah sebanyak 75 laporan keuangan terdiri dari laporan posisi keuangan dan harga penutupan saham yang terdiri dari 15 perusahaan dari tahun 2014 sampai dengan 2018.

\section{Tempat dan Waktu Penelitian}

Penelitian dilakukan secara tidak langsung ke perusahaan yaitu melalui Bursa Efek Indonesia yang berlokasi di Jalan PH.H. Mustofa No.33, Neglasari, Cibeunying Kaler, Neglasari, Cibeunying Kaler, Kota Bandung, Jawa Barat 40124 Telp. (022) 20524208. Adapun waktu pelaksanaan penelitian dimulai pada Maret 2019 sampai dengan Agustus 2019.

\section{Metode Pengujian Data}

\section{Uji Asumsi Klasik}

Sebelum dilakukannya Analisis Regresi Linear Berganda maka perlu adanya uji asumsi klasik terlebih dahulu agar memperoleh hasil yang lebih akurat. Asumsi yang digunakan antara lain :

a. Uji Normalitas, untuk menidentifikasi distribusi normal atau tidak.

b. Uji Multikolinearitas, untuk mengetahui ada tidaknya korelasi antar variabel bebas. c. Uji Heterokedastisitas, untuk mengetahui dalam sebuah model regresi terjadi ketidaksamaan variabel.

d. Uji Autokorelasi, untuk mengetahui apakah dalam sebuah model regresi linier terdapat hubungan yang kuat baik positif maupun negatif antar variabel.

\section{Analisis Regresi Linear Berganda}

Dalam penelitian ini, analisis regresi linier berganda bertujuan untuk mengetahui seberapa besar harga saham dapat dipengaruhi oleh current ratio.

\section{Analisis Korelasi}

Untuk mengukur ada atau tidaknya hubungan linier antara Current Ratio (X) dan Harga Saham (Y) serta mempunyai tujuan untuk meyakinkan bahwa pada kenyataannya Harga Saham dapat dipengaruhi oleh Current Ratio dan Debt to Equity Ratio.

\section{Koefisien Determinasi}

Untuk mengetahui besarnya pengaruh Current Ratio (X) dan Harga Saham (Y) dengan menggunakan analisis koefisien determinasi atau disingkat $\mathrm{Kd}$ yang diperoleh dengan mengkuadratkan koefisien korelasinya.

\section{HASIL PENELITIAN DAN \\ PEMBAHASAN}

\section{Hasil Penelitian Analisis Deskriptif}

Diketahui bahwa rata-rata Current Ratio (CR) pada Perusahaan Sub Sektor 
Perdagangan Eceran yang terdaftar di Bursa Efek Indonesia Periode 2014-2018 sebesar $4,86 \%$ dengan nilai minimum sebesar $0,54 \%$ dan nilai maksimum sebesar $25,6 \%$.

\section{Hasil Analisis Verifikatif}

\section{Uji Asumsi Klasik}

\section{a. Uji Normalitas}

Adanya titik-titik mengikuti garis diagonal meskipun sedikit menyebar tetapi penyebarannya tidak terlalu jauh dari garis diagonalnya,

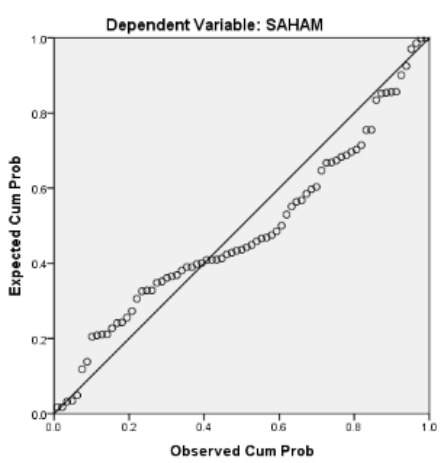

Gambar 1: Uji Normal Probability Plot

Tabel 1: Hasil Uji Normalitas

\begin{tabular}{llr}
\hline & & \multicolumn{2}{c}{$\begin{array}{c}\text { Unstandardized } \\
\text { Residual }\end{array}$} \\
\hline $\mathrm{N}$ & & 75 \\
Normal & Mean & 760.390 \\
Parameters $^{\text {a.b }}$ & Std. & \\
& Deviation & .115 \\
& Absolute & .115 \\
& Positive & $* .110$ \\
Kolomogorov- & Negative & .993 \\
$\begin{array}{ll}\text { Smirnov Z } \\
\text { Asymp. Sig. }\end{array}$ & & .278 \\
(2-Tailed) & & \\
\hline
\end{tabular}
a. Test distribution is Normal
b. Calculated from data

Tabel 1 menunjukan nilai Asymp. Sig. (2-tailed) dari kedua variabel tersebut lebih besar dari 0,05 maka distribusi data tersebut dinyatakan normal.

\section{b. Uji Multikolinearitas}

VIF yang dihasilkan $1,000<10$ dan tolerance $1,000>0,10$ yang artinya tidak terjadi gejala multikolinearitas pada data.

Tabel 2: Hasil Uji Multikolinearitas

\begin{tabular}{llcc}
\hline Model & & \multicolumn{2}{c}{ Collinearity Statistics } \\
\cline { 3 - 4 } & & Tolerance & VIF \\
\hline 1 & (Constant) & & \\
& CR & 1.000 & 1.000 \\
\hline
\end{tabular}

\section{c. Uji Heterokedastisitas}

Tidak dtemukan heteroskedastisitas, terlihat pada grafik scatterplot (gambar 2) yang menunjukkan adanya pola yang sangat jelas diikuti dengan titik yang tersebar baik di atas maupun dibawah angka 0 pada sumbu horizontal yaitu Y.

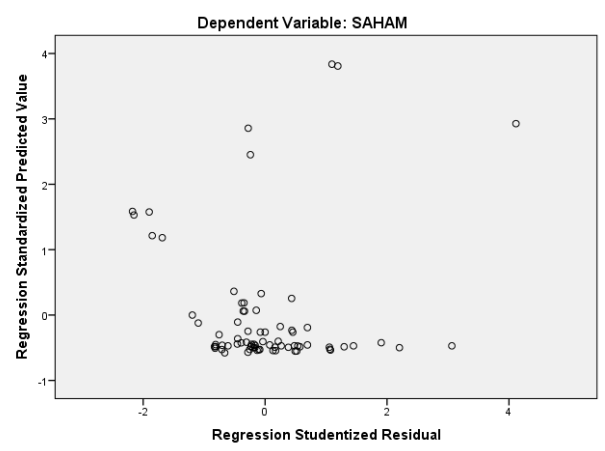

Gambar 2: Hasil Uji Heterokedastisitas

\section{d. Uji Autokorelasi}

Durbin-Watson adalah salah satu pengujian yang umumnya digunakan termasuk yang digunakan pada penelitian ini. Rumus nilai yang digunakan melalui Durbin 
Watson $=1,095$ dengan jumlah variabel bebas $(\mathrm{k})=1$, sample $(\mathrm{n})=75$ dan $\mathrm{du}=1,652$. Maka $\mathrm{du}<\mathrm{dw}<4-\mathrm{du},(1,652<1,095<2,348)$, sehingga dapat disimpulkan tidak terdapat autokorelasi.

Tabel 3: Tabel Uji Autokorelasi

\begin{tabular}{cc}
\hline Model & Durbin-Watson \\
\hline $\mathbf{1}$ & $\mathbf{1 . 0 9 5}$ \\
\hline
\end{tabular}

\section{Pengujian Hipotesis}

Pengujian Hipotesis CR terhadap Harga Saham

Hasil penghitungan nilai statistik uji $\mathrm{t}$ yang diperoleh menunjukkan t-hitung untuk variabel Current Ratio (X) lebih besar dari $\mathrm{t}_{\text {tabel }}(\mathrm{t}=6,731>1,993)$, maka diperoleh hasil pengujian Ho ditolak. Hasil ini juga ditunjukkan oleh nilai signifikansi uji statistik ( $p$-value) untuk variabel $\mathrm{X}$ sebesar 0,005 . Artinya kesalahan untuk mengatakan ada pengaruh dari Current Ratio (X) terhadap Harga Saham sangat kecil atau berarti lebih kecil dari tingkat kesalahan yang dapat diterima sebesar $5 \%$.

\section{Analisis Regresi Linear Sederhana}

Dari perhitungan koefisien regresi dapat diketahui bahwa persamaan regresi sederhana yang digunakan adalah sebagai berikut: Dimana : Y = Harga Saham X $=$ CR

1. Nilai konstanta sebesar 448,383 . Hal ini menunjukkan bahwa apabila semua variabel independent bernilai 0 , maka harga saham bernilai 605.146.
2. Current Ratio (X) mempunyai koefisien regresi bertanda positif sebesar 87,321 Hal ini menunjukkan bahwa setiap penambahan 1 persen Current Ratio akan meningkatkan harga saham sebesar Rp.84.104.

\section{Koefisien Determinasi}

Besar pengaruh Current Ratio terhadap Harga Saham pada Perusahaan Sektor Perdagangan dan Eceran dapat di hitung dengan perhitungan : $\mathrm{Kd}=(\mathrm{r}) 2 \times 100 \%=$ $(0,619) 2 \times 100 \% \mathrm{Kd}=38,32 \%$ Berdasarkan hasil perhitungan di atas maka faktor lain yang yang tidak diteliti yang berpengaruh terhadap harga saham diluar Current Ratio (CR) adalah sebesar sebesar $61,68 \%$.

Tabel 4: Koefien parsian Current Ratio Terhadap Harga Saham

\begin{tabular}{llll}
\hline & & CR & SAHAM \\
\hline CR & Pearson & 1 & .619 \\
& Correlation & & \\
& Sif.(2-tailed) & & .000 \\
& $\mathrm{~N}$ & 75 & 75 \\
\hline SAHAM & Pearson & .619 & 1 \\
& Correlation & & \\
& Sif.(2-tailed) & .000 \\
& $\mathrm{~N}$ & 75 & 75 \\
\hline **. Correlation is significant at the 0.01 level (2- \\
tailed)
\end{tabular}

\section{Pembahasan}

Pengaruh Current Ratio terhadap Harga Saham

Berdasarkan hasil penelitian menunjukkan bahwa Current Ratio mempunyai pengaruh yang memiliki hubungan yang kuat dengan harga saham yang positif, yang artinya apabila Current 


\section{Nominal: Barometer Riset Akuntansi dan Manajemen \\ P-ISSN: 2303-2065 E-ISSN: 2502-5430 \\ Volume 10 No 1 (2021)}

Ratio mengalami peningkatan maka akan diikuti dengan meningkatnya harga saham dan sebaliknya. Besarnya pengaruh Current Ratio terhadap harga saham pada perusahaan Perdagangan Eceran adalah sebesar 38,32\% sedangkan sisanya sebesar $61,68 \%$ dipengaruhi oleh faktor lain seperti return on asset (ROA), return on equity (ROE), net profit margin (NPM), price earning ratio (PER), deviden per share (DPS).

Hal ini sejalan dengan teori yang dikemukakan Irham Fahmi (2012:99) menyatakan bahwa ketika perusahaan memiliki likuiditas yang tinggi maka para investor akan tertarik terhadap perusahaan tersebut a dan akan berimbas pula pada harga saham yang cenderung akan naik karena tingginya permintaan pada saham tersebut (Christine Dwi Karya. 2012).

Hal ini sejalan dengan hasil penelitian terdahulu yang dilakukan Jeany Clarensia et. Al (2011), variabel Current Ratio terhadap Harga Saham, berdasarkan hasil penelitian maka dapat diketahui Current Ratio berpengaruh terhadap harga saham pada perusahaan manufaktur.

Investor yang telah berinvestasi di perusahaan perdagangan ritel tidak benarbenar berpikir bahwa investasi akan terjadi dalam jangka pendek dengan indikator Current Ratio, di mana perusahaan membayar kewajiban jangka pendeknya. Perusahaan perdagangan ritel memiliki investasi jangka pendek dan lebih banyak utang jangka panjang mereka diinvestasikan dalam sarana perdagangan ritel yang dimiliki oleh perusahaan. Investor sebenarnya sangat akrab dengan perusahaan dan oleh karena itu mereka dipandu oleh indikator jangka panjang lainnya, aset yang sifatnya tetap dengan sarana transportasi yang dimiliki perusahaan.

Semakin tinggi Current Ratio semakin besar kemampuan perusahaan untuk membayar kewajiban jangka pendek (Marie Ligocka \& Daniel Stavarek, 2019). Current Ratio merupakan rasio likuiditas dimana para kreditor mengukur operasi perusahaan dengan melihat apakah aktiva lancar perusahaan dapat memenuhi kewajiban jangka pendeknya saat kewajiban jangka pendek ini segera ditagih atau saat jatuh tempo. Karena semakin tinggi CR maka semakin besar kemampuan perusahaan dalam melunasi hutang-hutangnya

\section{SIMPULAN DAN SARAN}

\section{Simpulan}

Current Ratio (CR) berpengaruh terhadap Harga Saham pada Perusahaan Perdagangan Eceran Periode 2014-2108 memliki hubungan positif antara Current Ratio dengan Harga Saham, artinya apabila Current Ratio mengalami peningkatan maka Harga Saham ikut meningkat begitu juga dengan sebaliknya (Hakkı Öztürk \& Tolun A. Karabulut, 2018). 


\section{Saran}

1. Bagi Perusahaan

Bagi perusahaan sub sektor perdagangan eceran yang terdaftar di BEI disarankan kepada perusahaan untuk lebih memperhatikan Current ratio agar meningkatkan produktifitas perusahaan dan meningkatkan laba perusahaan yang akan menarik investor dan dapat meningkatkan harga saham.

2. Bagi Investor

Bagi para investor dan calon investor disarankan untuk memperhatikan rasiorasio keuangan perusahaan dalam mengambil keputusan investasi agar memberikan hasil yang terbaik.

3. Bagi Peneliti Selanjutnya

Bagi peneliti selanjutnya yang tertarik dengan penelitian di bidang pasar modal disarankan untuk mempertimbangkan factor fundamental lainnya yang mempengaruhi perubahan harga saham serta mampu memberikan informasi tambahan dalam memprediksi harga saham.

\section{DAFTAR PUSTAKA}

Birgham. (2014). Manajemen Keuangan. Jakarta: Erlangga.

Clarensia, J., Rahayu, S., \& Azizah, N. (2011). Pengaruh Likuiditas, Profitabilitas, Pertumbuhan Penjualan dan Kebijakan Deviden Terhadap Harga Saham (Studi Empirik Pada
Perusahaan Manufaktur yang Terdaftar di Bursa Efek Indonesia tahun 20072010. Jurnal Keuangan Universitas Budi Luhur, 1-17.

Dita, Chandra, N., \& Saifi, M. (2017). Pengaruh Economic Value Added (EVA), Net Profit Margin (NPM), Return On Equity (ROE), dan Return On Investment (ROI) terhadap Harga Saham (Studi pada Perusahaan Jasa Sektor Infrastruktur, Utilitas, dan Transportasi yang Terdaftar di BEI. Tahun 2013-2015). Jurnal Administrasi Bisnis, 122-130.

Egam, Gerald Ey, V. I., \& Pengerapan, S. (2017). Pengaruh Return On Asset (ROA), Return On Equity (ROE), Net Profit Margin (NPM), dan Earning Per Share (EPS) terhadap Harga Saham Perusahaan yang Tergabung dalam Indeks LQ45 di Bursa Efek Indonesia Periode Tahun 2013-2015. Jurnal Riset Ekonomi, Manajemen, Bisnis Dan Akuntansi, Volume 5 (Issue 1).

Fahmi, I. (2012). Pengantar Pasar Modal. Bandung: Alfabeta.

Hakkı Öztürk \& Tolun A. Karabulut. (2018). The Relationship between Earnings-toPrice, Current Ratio, Profit Margin and Return: An Empirical Analysis on Istanbul Stock Exchange. Accounting and Finance Research. Vol. 7, No. 1.

Ismail, W. (2016). Pengaruh Current Ratio dan Struktur Modal terhadap Laba Per Lembar Saham pada Perusahaan Pertambangan Batubara yang Terdaftar di BEI. Jurnal Berkala Ilmiah Efisiensi, Volume 6 (Issue 1).

Karya, C. D. (2012). Analisis Pengaruh Perbandingan Likuiditas, Solvabilitas dan Prifabilitas Terhadap Harga Saham Pada Perusahaan LQ45. Jurnal Akuntansi, 165-174. 
Kasmir. (2017). Analisis Laporan Keuangan. Jakarta: Raja Grafindo Persada.

Marie Ligocka \& Daniel Stavarek. (2019). The Relationship Between Financial Ratios and The Stock Prices of Selected European Food Companies Listed on Stock Exchanges.

Riyanto, B. (2013). Dasar - dasar Pembelajaran Perusahaan. Yogyakarta: BPFE.

Sri Dewi Anggadini \& Eva Tarsiah (2017). The Influence of Net Profit Margin and Current Ratio on Stock Price. Jurnal Riset Akuntansi - Volume IX/ No.2.

Sri Dewi Anggadini (2018). Faktor-Faktor yang Mempengaruhi Laba Bersih. Jurnal Riset Akuntansi UNIKOM, 1-7.

Sugiyono. (2017). Metode Penilaian Kuantitatif, Kualitatif dan R\&D. Bandung: Alfabeta.

Suhayati, E., \& Anggadini, S. D. (2009). Akuntansi Keungan - Edisi Pertama. Yogyakarta: Graha Ilmu.

Tahir Akhtar. (2020). Market Multiples and Stock Returns Among Emerging and Developed Financial Markets. Borsa Istanbul Review

Tan, Syamsurijal, Sarif, A., \& Ariza, D. (2014). Analisis Faktor-Faktor yang Mempengaruhi Harga Saham pada Industri Transportation Services di Bursa Efek Indonesia Tahun 20092012. Jurnal Dinamika manajemen, 116-128.

Umi, N, Sri Dewi A \& Linna I (2010). Penulisan Karya Ilmiah. Jakarta: Genesis.
Yemima, A. (2012). Analisis Pengaruh Current Ratio, Debt to Equity Ratio dan Total Asset Turnove. 